\title{
Australian Supermarket Consumers and Gender Differences Relating to their Perceived Importance Levels of Store Characteristics.
}

*Dr. Gary Mortimer Queensland University of Technology, Queensland

Dr. Peter Clarke Griffith University, Queensland

*Dr Gary Mortimer

QUT Business School

Queensland University of Technology

George St, BRISBANE QLD 4000

Phone: +61 731385084

Fax: +61 731381811

Email:gary.mortimer@qut.edu.au

Dr. Peter Clarke

Department of Marketing

Griffith Business School

Griffith University, Nathan Campus

170 Kessels Road

NATHAN QLD 4111

Phone: +61 737357352

Fax: $\quad+61737357126$

Email: p.clarke@griffith.edu.au 


\title{
Australian Supermarket Consumers and Gender Differences Relating to their Perceived Importance Levels of Store Characteristics.
}

\author{
Abstract \\ Family grocery shopping is the accepted domain of women; however, modern social and \\ demographic movements challenge traditional gender roles within the family structure. Men \\ now engage in grocery shopping more freely and frequently, yet the essence of male \\ shopping behaviour and beliefs present an opportunity for examination. This research \\ identifies specific store characteristics, investigates the perceived importance of those \\ characteristics and explores gender, age and income differences that may exist. A random \\ sample collection methodology involved 280 male and female grocery shoppers was selected. \\ Results indicated significant statistical differences between genders based on perceptions of \\ importance of most store characteristics. Overall, male grocery shoppers considered \\ supermarket store characteristics less important than female shoppers. Income did not affect \\ shoppers’ level of associated importance; however respondents’ age, education and \\ occupation influenced perceptions of price, promotions and cleanliness.
}

\section{Keywords:}

Gender, Supermarket Retailing, Store Characteristics. 


\section{Introduction}

Previous Australian studies examined important supermarket characteristics and influencers of satisfaction, yet failed to consider the effect of gender, income and age (Miranda, Konya et al., 2005).Additionally, other research compared cultural differences in satisfaction levels of Australian shoppers in general, but did not specifically address supermarket shopping or how gender influences choice (Jones, Vilches-Montero et al., 2010). Internationally, there has been a steady stream of consumer behaviour studies that point to the growth and presence of male shoppers in food shopping since the 1980s (Davis and Bell, 1991; Piper and Capella, 1993; Polegato and Zaichkowsky, 1994; Mazumdar and Papatla, 1995; Otnes and McGrath, 2001; Torres, Summers et al., 2001; Richbell and Kite, 2007). In light of these studies, and the growth of male shoppers undertaking food shopping in Australia, an opportunity exists to examine whether consumer traits, particularly gender, influence the choice of supermarkets (Ambler, Braeutigam et al., 2004; Beynon, Moutinho et al., 2010).

The purpose of the present study is to examine the attitudes and beliefs of male and female grocery shoppers in the Australian retail context. It seeks to identify perceptions of store characteristics by male and female shoppers and investigates the differences in the extent of the importance placed upon these characteristics. In addition, the study also addresses the effect of age, income, occupation or education on the consumers' perceptions towards store characteristics. The contribution of this paper is twofold. The first contribution concerns the notion that men and women are socialised differently and thereby, presents a view that these differences play an important role in the retail context, which in turn influences the choice of supermarkets. Such investigations provide the first steps towards a greater understanding of the behaviours of the emergent male grocery shopper. Three research questions guide this study:

1) Do male and female grocery shoppers consider store characteristics differently? 
2) Which store characteristics do male and female shoppers perceive as more important?

3) Does the age, income, education or occupation of the consumer affect the level of importance placed on store characteristics?

The literature discussion takes a step by step approach to address the theoretical background and development of relevant hypotheses. The appropriate research methods are identified and used to investigate the differences in the extent of importance placed upon store characteristics by male and female shoppers. A secondary goal seeks to understand the importance placed on supermarket store characteristics according to age, income, occupation and education. There is a discussion of key findings and implications for retailers.

\section{Literature Review}

\section{Gender, Grocery Shopping Behaviour and Store characteristics}

Sex-role theory defines gender as an individual, dichotomous and physical differentiating role that is relatively static and learnt in childhood. Gender theory suggests a system of inequality that is formed and reformed through daily experiences (Potuchek, 1992). Gender scholars favour a social constructionist approach to understanding and explaining gender (Courtenay, 2000; Fox and Murray, 2000; Leaper, 2000; Poggio, 2006). Simply, gender is shaped through the institutional and social mores and is constantly redefined through the everyday individual practices and interactions (Poggio, 2006). As such, gender identities generate within dynamic and shifting social contexts (Collinson and Hearn, 1996; Courtenay, 2000) because culture and society are more powerful explanatory mechanisms than nature and biology (Synott, 1993; Shilling, 2003). The traditional male gender roles no longer exist as clearly defined social barriers to familial roles. This merging of traditional familial roles, and society's acceptance of these shifts, means that more men now undertake traditional female gendered roles such as grocery shopping (Davis and Bell 1991; Dholakia, Pedersen et al. 1995; Dholakia, 1999; Gardner, 2004; Richbell and Kite, 2007). Generally, men who report 
to be the main grocery shopper are employed in white-collar, professional occupations, have higher levels of education and income when compared with men who do not undertake the grocery-shopping duty (Piper and Capella, 1993) and are mostly less than 34 years of age (Dholakia, 1999). Additionally, the admitted grocery-shopping males tend to search deliberately and limit price comparisons and pre-planning before shopping. There is also a social aspect of male grocery shopping that invokes different motivations (Piron, 2002).

A merging of traditional familial roles and societal shifts mean that more men now adopt broader, gendered roles toward family chores and grocery shopping duties. Fitting within a gender-balance domain, men mainly undertake the grocery-shopping task because their wives work (Piron, 2002). This factor of female labour-force participation is widely recognised as a driving force behind males undertaking the grocery-shopping task (Zeithaml, 1985; Blair and Lichter, 1991; Harris and Firestone, 1998; Murcott, 2000). Piron (2002) argues that male respondents believed men should take a more active role in shopping and viewed grocery shopping as a family activity rather than a responsibility of the household female. Men often act as influencers in the grocery decision-making process. Otnes and McGrath (2001) sought an understanding of the perception and action styles related to male shopping behaviour. Three stereotypical models of male shopping behaviour emerged: grab and go; whine and wait; and fear of the feminine. They further contended that men search deliberately, limit price-comparison shopping and browse infrequently - views supported by other researchers (Mazumdar and Papatla, 1995; Thomas and Garland, 2004).

Men took less time to complete the shopping task, purchased fewer items than women but paid a higher price per item. When comparing the speed of the shopping task with the number of items purchased, men appeared to take less time to select products then women. A male’s expenditure was higher per minute than the females, which coincided with the view that men seldom comparison shop (Davies and Bell, 1991). Dholakia’s (1995) exploratory 
work made it clear that men shop for groceries with greater frequency than women and purchased fewer items than women (Davies and Bell, 1991).

In demonstrating a preference for store loyalty, men routinely patronised the same store while women were more inclined to shop around for the best buy. Men favoured a wide product range with quality fresh produce and meat (Donegan, 1986) together with clearly identifiable pricing. As such, men consider objective criteria more important than subjective criteria in the decision-making process (Williams, 2002). Polegato and Zaichowsky (1994) note that helpful assistants, friendly checkout operators and easy parking were more important store characteristics for women. Researchers considered the levels of enjoyment and satisfaction by men in the grocery-shopping task (Dholakia, Pedersen et al., 1995; Dholakia, 1999; Torres et al., 2001). Men who claim to be the main grocery shopper enjoyed the task and, in general, men gain positive reinforcement from the family's appreciation of their involvement in grocery shopping. In task management, men appear not to ask for assistance; used shopping lists less frequently than women; did not compare prices or use catalogues; and did not stick to a defined budget. Male behaviour in the supermarket is very different from female behaviour (Gardner, 2004).

Since behavioural differences exist between genders, differences in perceptions towards the physical characteristics of supermarkets should also exist. Accordingly, this paper seeks to contribute and extend knowledge of consumer behaviour by identifying which store characteristics male and female shoppers perceive as more important and influence their choice of supermarket.

Different store characteristics present important decision criteria for consumers in their willingness to patronise particular stores. Helgesen and Nesset (2010) define a store characteristic as a physical attribute of the store that a consumer will reference and evaluate, in order to make choice decisions about the store. These include product characteristics such 
as merchandise range and availability; merchandise freshness and quality as well as ambient characteristics such as cleanliness and atmospherics. Other aspects are service features such as staffing competence, friendliness and speed of check out service as well as convenience and trading hours (Helgesen and Nesset, 2010).

\section{Hypotheses Development}

The term product has two meanings appropriate to this research paper. The first refers to the physical stock for sale and the second concerns service delivery. The availability of merchandise, including advertised promotional specials, is an important characteristic of a supermarket (Andreyeya, Blumenthal et al., 2008; Trautrims, Grant et al., 2009)to the extent that on shelf availability is a major concern for consumers. Consumer reactions to stock outs have significant coverage over the past 40 years and indicate consumers' reaction to out of stocks is generally consistent (Corsten and Gruen, 2003).

Shoppers, when faced with a product being unavailable for purchase, will elect to substitute the product, delay the purchase or leave empty handed. This is often referred to as SDL substitute, delay or leave (Zinn and Liu, 2001; Zinn and Liu, 2008). Associated with any retail establishment are the physical location of stock and the ease of flow through the store. An oft used product description is the word - quality. Quality is an important characteristic that generally describes a standard of fresh food available in the store. The perceived quality of fresh produce is influential in a shopper's decision to visit a particular store (Helgesen and Nesset, 2010). Accordingly, three Product focussed hypotheses are developed and presented for testing.

H1: Being in stock of specials throughout the week is of less importance to men than to women.

H2: Well-stocked shelves are of less importance to men than to women.

H3: High quality fresh food is of less importance to men than to women. 
The second product interpretation concerns the complex perceptions of service quality (Seth, Deshmukh et al., 2005). Overall, the aim of a store is to enhance the buying experience, increase the probability of repeat purchases and foster spending. Ultimately, service quality appears as a critical decision criterion when selecting a supermarket (Helgesen and Nesset, 2010). The key service encounter in supermarkets is the friendliness of the service personnel together with accuracy and speed of the checkout experiences (Helgesen and Nesset, 2010). Such immediate interactions contribute to the company image formed through customer's interpretation of the store identity and presentation. It has been suggested elsewhere that women may be more sensitive to relational aspects of a service encounter and men to core aspects, such as speed and efficiency (Beynon et al., 2010). Although consumers have traditionally viewed the supermarket as a provider of food ingredients, supermarket retailers are now offering meal solutions and prepared foods in an attempt to capture a larger share of the family spend. Accordingly, consumers evaluate cleanliness and hygiene as important characteristics (Schurer, 1997). Cleanliness is one of the highest ranked store characteristics, across supermarket retail formats (Carpenter and Moore, 2006) and is the second most important factor in the ongoing performance of a supermarket (Min, 2010). As hallmark offerings, product and quality may not be sufficient enticement to patronize a particular store. As such, two hypotheses developed from the Service literature are presented below.

H4: Well-staffed, serviced departments are of less importance to men than to women.

H5: Accurate and friendly register operators are of less importance to men than to women.

Store location, convenience, parking facilities, transport to and from the store and trading hours are contributing factors to supermarket venue choices (Solgaard and Hansen, 2003; Hansen, 2005; Carpenter and Moore, 2006; Helgesen and Nesset, 2010). It is recognised shoppers may be unwilling to change supermarkets, as they would risk giving up store specific knowledge (Beynon, Moutinho et al. 2010). That car parking is of little interest to 
men tends to suggest they feel at ease in accessing the supermarket, or they are travelling alone and need not concern themselves with heavy shopping bags and children (Torres, Summers et al. 2001). Three hypotheses relating to location are presented for testing.

H6: Easy parking is of less importance to men than to women.

H7: Convenient locations are of less importance to men than to women.

H8: Store cleanliness is of less importance to men than to women.

Apart from range and convenience, there is a perception that price is the ultimate purchase criteria. Low price and promotional pricing are common characteristics (Dickson and MacLachlan, 1990; Mazumdar and Papatla, 1995; Bronnenberg and Vanhonacker, 1996; Urbany, Dickson et al., 1996), while discount coupons become determinants of supermarket choice. Research identifies that men will generally buy what they always buy: same size, same brand and same flavour (Otnes, Lowrey et al., 1997; Dholakia, 1999; Noble, Griffith et al., 2006). Although price may be the main evaluative criterion considered by men when shopping for groceries, it is not considered high enough to affect the overall selection process (Otnes et al., 1997; Underhill, 1999; Noble et al., 2006). In their study of male supermarket shopping behaviour, Mazumdar and Papatla (1995) indicate that men are comparatively price insensitive, not influenced by special prices, large displays or promotional advertising to the extent that price is not the most important characteristic. To men, supermarket shopping is a purely purchase-driven activity (Mazumdar and Papatla, 1995; Campbell, 1997). Helgesen et al (2010) maintained check out service quality appears as a more important antecedent of overall store satisfaction than price and suggests a task-driven approach is appropriate for supermarket shopping. Whilst promotion covers media presence, the most effective tools are catalogues and well presented, easy to read shelf label prices. From a simplistic marketing view, customers value the 'Four Ps' associated with the characteristics of store shopping. In addition, planning, tasks and list making are the responsibility of the shopper and compliment 
the characteristics of the store. A final two hypotheses developed from the Price and Promotion literature are:

H9: Weekly specials are of less importance to men than to women.

H10: Low prices are of less importance to men than to women.

\section{Age, Education, Income or Occupation}

Relevant social shifts cover access to greater levels of post-secondary education for both sexes (Harris and Firestone 1998); the impact of feminist ideology on contemporary males (Hochschild 1989; Buzar, Ogden and Hall 2005) and increases in the employment participation rates of women outside the home (Richbell and Kite 2007). Cultural and social shifts over the last few decades point to a noticeable increase of younger male grocery shoppers is evident because the samples appear to have a higher proportion of younger males under the age of 54 years (Piper and Capella 1993; Polegato and Zaichkowsky 1994) . Other views suggest that there was more joint sharing or primary undertaking of grocery shopping among younger respondents (Dholakia, Pedersen et al. 1995; Dholakia 1999). Older males are more likely to employ written shopping lists than younger men because lists help navigate their way around the store and locate specific departments. (Zeithaml 1985; Polegato and Zaichkowsky 1994; Thomas and Garland 2004). Age can impact on enjoyment levels. Because younger men appear disengaged and are generally unhappy when shopping; older men are either bored or disinterested (Otnes and McGrath 2001).

Some of the shift toward non-traditional ideas about the roles of men and women grow out of the higher levels of education among all groups compared to past generations (Harris and Firestone 1998). As such, men and women who attain higher levels of education tend to develop non-traditional gender roles within the home to the extent that the higher educated the couple, the more role sharing took place within the family.(Qualls 1987; Biernat and Wortman 1991; Belch and Willis 2002). Increasingly, education has been seen as a life-long 
learning process, with the higher education system not only providing for the 17-19 years age group, but also as a community resource with the flexibility and adaptability to cope with the needs of different people at different stages of their lives and careers (ABS 2005c). Men with higher levels of education became more involved in housework due to greater exposure to, and acceptance of societal change (Goldscheider and Waite 1991; Baber and Allen 1992; Commuri 2000) where younger men consistently adopted non-traditional family roles (Allen and Webster 2001).

Recent social and demographic movements initiated changes to traditional gender roles within the household (Murcott 2000; Szinovacz 2000; Bhatti and Srivastava 2003; Richbell and Kite 2007). Women have access to improved levels of income and are often engaged in professional occupations (Blair and Lichter 1991; Harris and Firestone 1998; Murcott 2000). There is now a greater acceptance of working mothers and, alternatively, fathers choosing to be home-stay parents and are either voluntarily or by necessity engaging in supermarket shopping (Davis and Bell 1991; Dholakia, Pedersen et al. 1995; Dholakia 1999; Gardner 2004; Richbell and Kite 2007). Western industrialised nations, as a result of changes in the labour market, are beginning to identify new family role structures characterised by a more egalitarian division of labour at home and in the workplace (Potuchek 1992). Simply, the labour-force participation of women aligns with the acceptance of less traditional gender role attitudes (Harris and Firestone 1998) and is the most widely accepted reason for the increase of men shopping in supermarkets (Otnes and McGrath 2001; Richbell and Kite 2007).

\section{Method}

This study aims to identify differences between male and female grocery shoppers in the level of importance placed on specific store characteristics. Twenty five male and twenty five female undergraduate students with grocery shopping experience tested a pilot questionnaire that pointed towards several modifications for a final survey. The final version 
incorporated 30 items representing various aspects of the shopping experience that became the basis for a factorial series (see Table 1). Respondents' demographics helped to determine if levels of importance were affected by traits, other than gender, such as age, income, occupation and education. Whilst the main focus and hypotheses concentrate on concrete gender issues, further contributions to knowledge emerge as this paper integrates the effects of other demographical variables such as age, education income or occupation.

The first research question asked if male and female grocery shoppers consider specific store characteristics differently. The second, sought to identify which store characteristics that male and female shoppers considered more important. The final research question examined the effect of other independent variables.

INSERT: Table 1 - Store Characteristics, Items and Author/s

\section{Instrument, Sample and Procedure}

A face-to face questionnaire administered by one researcher was an appropriate data collection tool. Data entry followed and a subsequent analysis allowed insights and outcomes relating to shopping behaviours and attitudes toward store characteristics. The questionnaire began with an appropriate introduction that advised the respondent of the nature of the study, the proposed use of data, and addressed confidentiality and privacy issues. Table 1 outlines the characteristic, items measured and author sources openly adopted for the question content. Male and female grocery shoppers were asked to rate the relevant importance of each store characteristic on a five-point Likert-type scale where 1 was very important and 5 was very unimportant.

Previous sample sizes for grocery-shopping surveys included 70 to 120 respondents (Leong, 1993; Thomas and Garland, 2004) and gender-split samples of 40 male - 40 female responses (Davis and Bell 1991) and 75 each (Piron 2002). The sample used here drew from one major Australian capital city which coincidently, is moderately free from the significant ethnic 
cohorts germane to other capital cities. A quasi-probability sampling method ensured a representative sample of 140 male and 140 female grocery shoppers. All respondents in the sample claimed to be married or co-habiting. The definition applied to this study interprets a grocery shopper as a person who entered a supermarket with a basket or trolley to purchase food or household products and was not a supermarket employee, supplier or manager. A screening question eliminated those directly associated with the supermarket and revealed primary or shared responsibility for shopping. This study sought male and female grocery shoppers who primarily or equally undertake the weekly grocery-shopping task and all individual men and women observed entering a nominated supermarket were potential respondents.

In an effort to reduce sample bias, every fifth shopper was a potential participant in the study and the researcher moved to the next supermarket on fulfilment of a 35 male and female quota of shoppers from each of the four identified supermarkets. Although this research sought differences between genders, it was ill-considered to collect data from couples shopping together as the responses may incorporate response bias. Minors (under 18 years), were outside the sample specifications. Finally, the supermarkets of choice are the two market leaders who represent between 70 - 72 percent market share (IBIS World Industry Report, 2006).

\section{Analytical Approaches}

A series of statistical approaches sought identification and qualification of male and female attitudes and beliefs toward supermarket shopping and store characteristics. Firstly, the mean of each of the thirty singular, independent items reflected male and female consideration of the relative importance of the relevant characteristics and t-tests detailed significant differences. An exploratory factor analysis (EFA) sought a reduction of the thirty items to meaningful associations. Two directions eventuated from the EFA; the first delineated ten 
specific store characteristic factors and a subsequent, transform-compute procedure produced ten summated means variables, each with strong Cronbach’s Alpha’s. An independent samples t-test sought to identify significant statistical differences between constructs according to gender. Multivariate ANOVA was employed to test for significant differences between age, income, occupation and employment groups. Univariate ANOVA identified the strength of mean importance ratings between groups, based on gender, occupation, education and age.

\section{Results}

A simple comparison of means of the variables was undertaken (see Table 2) to identify which singular, independent characteristics were considered more importantly by each gender group. Mean scores of female shoppers fell between, 1.19 to 1.66 (very important important), on all thirty items and male shopper scores held much wider results of 1.23 to 2.81 (Important - Neutral).

\section{INSERT: Table 2 - Comparison of Means - Singular Store Characteristics Items and} Gender

The use of t-tests identifies significant statistical differences within the 30 singular, independent items. Differences exist between the gender on all, but two items pertaining to, service department staffing (sig. 0.745) and efficient register operations (sig. 0.738) (see

Table 2). Both gender groups produced one outlier, parcel pick up availability, female (mean 3.64) and male (mean 4.34). The results show 28 of the items report significant statistical differences in the level of importance placed on them. Female responses accounted for dominance in 26 items, male 2 items and 2 items held no statistical difference. Factors relating to convenience, ease of access and augmented services, like parcel pick up, fell outside the top ten most important characteristics and the item relating to friendly register operators was ranked 18th. 
The important independent supermarket characteristics male shoppers reported was, no waiting (1.24), getting served quickly (1.23) and efficient register operations (1.48).

Considered important by both men and women, was; well staffed service departments (1.63) and the weekly specials (1.84). The items, easy parking (2.20) and easy access to car park (3.01) tend toward neutral for male shoppers. Furthermore, convenient locations (2.29), easy to find (2.49) and easy to get to (2.56) were less important to male shoppers than female shoppers.

Overall, female shoppers considered all thirty singular items more important than that of males. The item concerning regular discounts (1.15) is the most important store attribute for women. The female shoppers nominated price, value for money and cleanliness as important. Specifically, female shoppers rated consistent pricing (1.19) as the next most important, followed by, competitive prices (1.20) and Low Prices Everyday (1.22). Both hygienic food handling processes and high quality food handling delivered important-level scores of 1.22. Female shoppers also reported easy parking (1.46) and easy access to car park (1.46) to be more important to them rather than to male shoppers.

An exploratory factor analysis reduced the 30 independent questions to 10 factors that represent shoppers perceptions of store characteristics (Table 3) All but two items (efficient operators - .514, parcel pick up - .598) produced high-loading markers. Cronbach’s alphas were all above, or near, a level of.70 which is generally satisfactory. Alphas ranged from .69 to .98 and generally demonstrated a high association.

\section{INSERT - Table 3 - Factor Structure of Store Characteristics about here}

The factors established in the previous section underwent a summation process to form composite variables that align with the ten hypothesis statements. A correlation test showed strong and positive correlations above .50 across the 10 items. Independent $t$-tests identified 
significant statistical differences between male and female grocery shoppers in relation to the levels of importance placed on each of the ten summated store characteristics by (Table 4).

\section{INSERT - Table 4 - Summated Constructs about here}

Ten hypotheses addressed the proposition that the importance attributed to a series of store characteristics by males would be less than the importance ascribed by females. The only hypothesis to fail was; (H4) Well-staffed, serviced departments are of less importance to men than to women. In reference to this item both male and female grocery shoppers assigned similar degrees of importance. The nine remaining hypotheses were proven in that males place less importance on selected characteristics than females would. Analysis of variation (ANOVA) alone identified significant differences existed between genders based on the perceived level of importance placed upon specific store characteristics. Multivariate ANOVA was then employed to examine if differences, associated with gender, where also present across other variables, such as age, income, education and occupation. (See Table 6) The literature identified that male grocery shoppers tend to be younger, employed in whitecollar, professional occupations, have higher levels of education and income when compared with men who do not affirm as a regular grocery-shopper (Piper and Capella, 1993; Dholakia, 1999). Hence, the testing sought to identify if these variables played a role in influencing importance attributed to specific store characteristics.

In preparing the data for testing, multiple age, income, education and occupation groups were reduced to two distinct levels. Age was recalculated to two groups, younger $<35$ years and older $>36$ years old. Income became low $<\$ 44 \mathrm{k}$ and high $>\$ 45 \mathrm{k}$, education became nontertiary and tertiary educated and the occupation variable was allocated Blue Collar, including trade and retail and White Collar, encompassing management, professional and education. (See Table 5) 
Significant statistical differences existed between the levels of importance assigned to store characteristics by gender, with the exception of sufficient and efficient staffing (sig. 0.686). Age and income, independently, had no affect on the level of importance placed on store characteristics. No significant statistical differences were detected between young or old, low and high income earners. When the variable, education, was examined, only the items associated with store cleanliness and hygienic processes appeared to demonstrate differences (sig. 0.048). Occupation of the consumer, either white or blue collar, affected the perceived importance of only one item; consistent, stable prices (sig. 0.028). This was evident when the shoppers' age and income were considered together (sig. 0.004). The importance of quality fresh food and produce was dependent of the shoppers' gender and education, with significant differences being noted (sig. 0.015). Age and education of the shopper affected their perception towards out of stocks (sig. 0.018) and food quality (sig. 0.025). Gender combined with occupation held differences in the perceived importance of fresh food quality (sig. 0.008). Age and the shoppers' occupation affected the level of importance attributed to convenience and store locality (sig. 0.030). Finally, perceptions of the importance of stable and consistent pricing were different between customers based on their age, income and occupation (sig. 0.006). Specials and regular promotions were also considered with varying degrees of importance, dependent upon the shoppers' gender, education and occupation (sig. 0.027).

Tertiary educated consumers were less concerned with the cleanliness of the store (mean 2.167) and may align with a 'grab n' go' cohort and expedite their shopping, giving little regard to hygiene and tidiness of the store environment. Significant differences existed between occupations and the level of importance placed on price (sig. 0.028). The occupation 
of the respondents influenced their level of importance placed on consistent, reliable and stable pricing. Customers employed in blue collar or trade occupations were more concerned with everyday, low and consistent pricing (mean 1.456). Differences were evident between age and income groups based on the level of importance ascribed to consistent low pricing (sig.0.004). Older consumers, earning less than AUD\$44,000 considered low and consistent pricing very important (mean 1.116), whereas consumers earning over AUD\$44,000 were not moved by price considerations. Accordingly, income and age affects the level of importance placed on pricing. Respondents' education had no direct impact on the level of importance placed on high quality, nutritional fresh produce, however when gender and education were considered together, differences were detected (sig.0.015). Female, non-tertiary educated consumers appeared to rate the quality attribute more importantly (mean 1.403) than male, non-tertiary educated consumers.

Differences were evident between tertiary and non-tertiary educated consumers based on the level of important attributed to being in stock (sig.0.018) and quality fresh food (sig.0.025). Non-tertiary educated, particularly younger, consumers reported that being in stock of wanted merchandise (mean 1.667) and quality (mean 1.632) were important attributes influencing their choice of supermarket. We identified significant differences between gender, occupation and perceptions of fresh food quality (sig.0.008). Gender had the stronger influence with female respondents reporting higher levels of importance attributed to quality fresh food than male respondents. However, within this group of female respondents, women employed in white collar, professional roles were more concerned with the quality fresh food. Differences were detected between Age and Occupation groups and the level of importance placed on convenience, location and trading times (sig.0.030). We identified that respondents, employed in blue collar or trade occupations were more aligned to supermarkets offering 
greater levels of convenience, than respondents employed in professional roles. Younger, trade qualified customers considered convenience most importantly (mean 1.679). Combining age, income and occupation variables, we determined significant differences existed on the level of importance placed on consistent, reliable and stable pricing (sig.0.006). There was an expectation that younger respondents, employed in blue collar occupations, earning less that AUD\$44,000 a year would patronise supermarkets offering consistent, stable, low prices. This was present in the findings (mean 1.297). However, two other groups reported consistent pricing as more important, older, low income, blue collar workers (mean 1.130) and white collar workers mean 1.000). We contend that older workers were more concerned with pricing as they may have more financial responsibilities. Finally, we explored the variables of gender, education and occupation on regular specials, discounts and promotional prices, identifying significant differences within the groups (sig.0.027). Once again, gender was a dominant influencer of importance levels, with female shoppers rating specials a more important motivator to shop at a particular supermarket. When education and occupation was considered, we found non-tertiary educated, blue collar, female workers were more concerned with regular specials and promotional pricing (mean 1.235). We determine this to be related to budgeting constraints on household expenditure.

\section{Discussion}

The ten hypotheses constructs determined in this study incorporate three singular and independent contributing items that are important characteristics of choice by supermarkets shoppers. The significant statistical differences between the levels of importance placed on these constructs relate to the ingrained shopping orientation of men and women. International research indicates that male shoppers seek information, attainment and 
convenience, while female shoppers valued uniqueness, assortment seeking and social interaction (Noble et al., 2006). Other research suggests men are goal orientated and women as socially orientated (Iacobucci and Ostrom, 1993). Whilst the hypotheses statements exhibited statistical differences in favour of women shoppers, some of the contributing items were male orientated. These findings identify a utilitarian approach to male shopping practices, as there is significant gender differences between the importance's placed on the characteristics of price and price comparison because price is a single, commonly understood concept. The singular and independent characteristics of weekly specials and low prices also hold significant statistical differences is important for male shoppers and fits well within a utility context.

The results are consistent with sociological theories of gender differences and support the idea that men and women are socialised differently and these differences play an important role in the retail context and experience. Anecdotally, men don't enjoy the shopping task or they are unwilling, unengaged participants in the exercise. However, this classic portrayal of the traditional male shopper type was not evident in this sample. Many gender difference studies examine a traditional scenario of couples and regular family shopping duties or roles. The production and popularity of kitchen, cooking or food programs featured on television depict the male hosts as being aspirational role models in food shopping and preparation. Good kitchen men know what they want, seek specific advice and are in control.

The steady growth of Australian male grocery shoppers leads toward males developing attitudes and beliefs about the importance of specific store characteristic. Such results align themselves with the literature suggesting male grocery shoppers tend to consider factors of efficiency and speed to be important. In contrast, other similar characteristics associated with speed, ease of access and efficiency, did not rate as highly important characteristics. As these 
items relate to locality and transport, expectations are that men, who shop on the way home from work, would not be concerned with ease of access or convenient locations.

This research identified that male respondents did not consider many of the individual store characteristics as important factors influencing their choice of shopping destination. Their importance rating of being served quickly and no waiting was greater than women's ratings. Efficiency was measured by the speed of the transaction rather than the friendliness or accuracy of the operator and the participating males sought well-staffed service departments and efficient checkout operators. Men did not rank friendly operators, accurate operators or helpful staff highly in surveys because the main concern was completing their shopping task in the fastest possible time.

Female shoppers considered weekly specials, regular discounts and promotional pricing more important than men. However, advertised specials and promotional items being in stock throughout the week presented mixed findings and this suggests further investigation is required. Although both men and women considered all three measures of the in stock characteristic to be important, the mean score of male respondents was somewhat higher on the singular item - stock I want. This tended to suggest that men were not concerned with stock-outs, but rather supermarkets being in stock of products they wish to buy.

Although our female sample reported the friendliness (social orientation) and cleanliness, other factors relating to value for money and price were considered more importantly. Respondents were asked to rate their level of importance as to everyday low pricing, consistent pricing, and competitive pricing. Although both male and female grocery shoppers indicated all three singular measures of pricing were important, male shoppers placed less importance on these criteria and thus exhibited different approaches to price evaluations along a time spent-dollar cost continuum. 
Men reported low importance levels on external supermarket characteristics such as car parking, easy access to and egress from the car park. Both male and female found the facility of parcel pick-up, to be unimportant where the low level attitude toward parcel pick-up suggests that both genders wished to carry their own purchases to the car themselves and, therefore, expedite the grocery-shopping activity. The customer controls the timing and effort associated with the purchase and delivery of the groceries. This self service syndrome encouraged by grocery retailers extends to customers for the transportation of purchases to the car, taxi or bus. If grocery shopping is about task management, then the shopping task is not complete until the groceries are in the cupboard or larder at home. The customer ensures no losses, yet accepts all responsibility.

Significant statistical differences were detected between the genders on the characteristic of convenient locations. On all measures, both male and female shoppers considered convenient locations important, however, men did not rate this level of importance as highly as did women. On the specific measure of easy to get to, the mean scores of male respondents tended to align more closely with a neutral position of neither important nor unimportant. This may suggest that male grocery shoppers are not deterred by the difficulties of getting to a supermarket, as long as it is easy to find and built in a convenient location. The difficulties in getting to the supermarket may include transport issues, work constraints and other temporal barriers. While our sample of male shoppers did report speed and expediency, they disregarded other factors related to convenience. Characteristics relating to parking, access and locality were not rated highly.

Significant differences were also discovered between male and female grocery shoppers in relation to their perception of the level of importance placed on store cleanliness and hygienic processes. On nearly all items, female shoppers considered store cleanliness and hygienic practices to be a more important factor than men. Related to store cleanliness and hygienic 
practices is the perception of fresh food quality. This idea related freshness to perceived healthiness and taste. Once again, it was found that male grocery shoppers placed less importance on these criteria and significant differences between the genders were present. Men may not be actively involved in the family meal preparation at home, hence maybe unaware of or deterred by poor procedures in food handling at the store level. Alternatively, men may purchase pre-packaged or tinned products that do not require the same level of food handling as for perishable items.

To summarise, men rated 26 items as less important than women did, rated 2 items as more important and showed no difference on another 2 items. This research identified getting served quickly, no waiting, efficient operators and well staffed service departments are the most important factors of supermarket shopping for men. By tradition men want to get in, get served quickly and get home. In contrast, female respondents to this survey rated the following aspects of grocery shopping to be most important: weekly specials regular discounts, consistent pricing competitive pricing, hygienic processes, food handling procedures and low prices. It is inferred from this analysis that female grocery shoppers appear more concerned with pricing, specials, discounts and food safety.

The contribution of the age, income, education and occupation variables was varied but offers new insights. The cleanliness of the store was more important to the lower educated cohort. Younger, professional female shoppers were more focussed on the quality of fresh food and produce. Older, lower paid workers were more concerned with consistent, low and stable prices. Regular specials and promotions were important to older, lower educated, female workers. The level of importance placed on price and returns to the initial premise that customers seek value and savings where possible. The possibility that the older shoppers live with restricted incomes and make every attempt to gain value through price variations is reasonable; however, younger shoppers seek similar value and savings for housing purchases 
or growing their family. If cheaper shopping is a predominant financial goal then store characteristics would not be an influential factor on either high or low income. Convenience and locality was important to younger, blue collar workers. As with any learning, the wider and deeper issues become more meaningful and associated with lifestyle due to tertiary and non-tertiary education. The paper argues that the more educated the consumer is, the more they are likely to be employed in a professional role and hence be too busy to concern themselves with the cleanliness and hygiene requirements, which consequently effects their evaluation of a supermarket and accordingly choice of patronage.

\section{Management Implications}

This article compares and contrasts important supermarket characteristics of male and female shoppers, it was equally important to address the store attributes women considered important. Earlier research suggested female shoppers were socially orientated shoppers, it was expected that identified important supermarket characteristics would not relate to factors of efficiency or speed, as they did with males (Noble, Griffith et al. 2006). Similar to other work, it is suggested these women were more compelled to save money, employ coupons, achieve greater transactional value and therefore indirectly contribute to the household budget (Lichtenstein, Netemeyer et al., 1990; Lichtenstein, Ridgeway et al., 1993; Mazumdar and Papatla, 1995).

Our study presents managerial insights into two important factors relating to supermarket shopping behaviour. Firstly, the paper contends that gender influences the choice of important supermarket characteristics and secondly, identifies which store characteristics are most important to supermarket shoppers. It provides opportunities for supermarket executives to develop strategies and allocate limited resources away from unimportant characteristics, (i.e. Parcel Pick Up) and into other store characteristics, such as customer service and pricing, which are considered much more importantly. 
The male grocery shopper represents a growing and important market for supermarket retailers in Australia. Accordingly, supermarket retailers can no longer describe their core shoppers as simply female, nor can they continue to ignore this important group of male shoppers. The Australian male shopper presents as a committed and regular shopper and is an attractive consumer group for supermarket retailers. Men shop regularly and appear committed to their local supermarket. They rarely check prices or consider complex product evaluative criteria. Most do not plan their purchases before entering the supermarket and, when shopping, many will purchase unplanned and impulse items. As the findings concluded; when faced with 30 store characteristics, men are only concerned about service levels and checkout efficiency.

Supermarket executives should consider strategies to target, attract and retain Australian male shoppers. It is argued that as men will make unplanned and impulse purchases when shopping; supermarkets should develop well-merchandised high-traffic areas, secondary locations and implement associated selling tactics. Price points should be kept to a minimum and able to be easily read at a quick glance.

Australian male grocery shoppers do not consider many store characteristics as important, other than service levels and efficient checkout operations. Therefore, in-store competitions, taste testing and other promotional activities are of little interest. These men simply want to get in and complete their shopping in the shortest possible time. This research identifies the after work and evening periods as being the most common times that men frequent supermarkets. Accordingly, management should focus efforts in service levels during these times to expedite the male shopping experience and attract this group. The study has provided new insights into an otherwise under-researched group of consumers and has afforded ideas and direction for supermarket retailers and management.

\section{Conclusion and Future Research}


The combined sample of 280 regular male and female grocery shoppers demonstrated that these shoppers place varying levels of importance on supermarket store characteristics. This research examined the attitudes and beliefs of male and female grocery shoppers in the Australian retail context. The main research question sought to identify important store characteristics and the importance placed on of these constructs by male and female shoppers. The overriding research objective was to identify which store characteristics male and female grocery shoppers consider as important and what differences exist between the levels of importance and the shopper's gender. To that end, the results demonstrate that male and female grocery shoppers consider important store characteristics differently and there are specific characteristics that men and women consider more important. All but one of the ten hypotheses is proven. Male shoppers considered speed, convenience and efficiency to be the most important factors. Female shoppers, in contrast, reported characteristics relating to pricing, cleanliness and quality.

These findings present new challenges for future research. It is proposed a more extensive measure be undertaken. It is also acknowledged that branding, packaging, labelling, generic product range and loyalty programs were overlooked in this case study. In addition, there may be specialist purchases that are outside the research interest. Males may purchase meat or vegetables and dominate these domains whereas women may dominate in non-food purchases and one avenue of research concerns a detailed assessment of across the range purchase responsibilities. Accordingly, further research is warranted to address these influencing agents. The characteristic of price generated mixed results and suggests further investigation in relation to the effect of gender.

Our findings are supported in some ways by earlier theoretical work of researchers into shopping orientations of gender (Iacobucci and Ostrom 1993; Noble, Griffith et al. 2006), however the process employed here detected conflicting themes. As with most research case 
studies, this work is not without its limitations. This research collected in one Australian capital city did not address issues of ethnicity that is characteristic of other Australian cities or the shopping formats in rural communities. Such research may explain and predict shopping behaviour, under certain conditions, and integrate market-place adaptations with increased certainty and with improved generalisability. 


\section{References}

ABS. (2005c). "4913.0 Pregnancy and Employment Transitions, Australia." Http://www.abs.gov.au/ausstats/abs /primarymainfeatures/4913.0

Ambler, T., S., S. Braeutigam, J. Stins, S. Rose and S. Swithenby (2004). "Salience and Choice: Neural Correlates or Shopping Desision?" Psychology and Marketing 21(4): 247-261.

Andreyeya, T., D. M. Blumenthal, M. B. Schwartz, M. W. Long and K. D. Brownell (2008). "Availability and Prices of Food Across Stores and Neighbourhoods: The Case of New Haven, Connecticut." Health Affairs 27(5): 1381-1388.

Belch, M. A. and L. A. Willis (2002). "Family Decision at the Turn of the Century: Has the Changing Structure of Households Impacted the Family Decision Making Process." Journal of Consumer Behaviour 2(2): pp. 111-125.

Beynon, M. J., L. A. Moutinho and C. Veloutsou (2010). "Gender Differences in Supermarket Choice: An Expositional Analysis in the presence of Ignorance using CaRBS." European Journal of Marketing 44(1): pp. 267-290.

Biernat, M. and C. B. Wortman (1991). "Sharing of Home Responsibilities between Professionally Employed Women and their Husbands." Journal of Personality and Social Psychology 60(6): pp. 844-860.

Blair, S. L. and D. T. Lichter (1991). "Measuring the Division of Household Labour: Gender Segregation of Housework among American Couples." Journal of Family Issues 12(1): pp. 91-113.

Bronnenberg, B. J. and W. R. Vanhonacker (1996). "Limited Choice Sets, Local Price Response and Implied Measures of Price Competition." Journal of Marketing Research 33(2): pp. 163-174.

Buzar, S., P. E. Ogden and R. Hall (2005). "Households Matter: The Quiet Demography of Urban Transformation." Progress in Human Geography 29(4): pp. 413-436

Campbell, C. (1997). Shopping, Pleasure and the Sex War. The Shopping Experience. P. Falk and C. Campbell. London, Sage Publications.

Carpenter, J. M. and M. Moore (2006). "Consumer Demographics, Store Attributes and Retail Format Choice in the US Grocery Market." International Journal of Retail and Distribution Management 34(6): 434-452.

Collinson, D. L. and J. Hearn (1996). Men as managers, managers as men: critical perspectives on men London, Sage.

Corsten, D. and T. W. Gruen (2003). "Desperately Seeking Shelf Availability: An Examination of the Extent, the Causes, and the Efforts to Address Retail Out-ofStocks." International Journal of Retail and Distribution Management 31(12): 605-612.

Courtenay, W. H. (2000). "Constructions of Masculinity and their Influence on Men's Well Being: A Theory of Gender and Health." Social Sciences and Medicine 50: 1385-1401.

Davis, G. and J. Bell (1991). "The Grocery Shopper - Is He Different?" International Journal of Retail and Distribution Management 19(1): pp. 25-28.

Dholakia, R. R. (1999). "Going Shopping: Key Determinants of Shopping Behaviours and Motivations." International Journal of Retail and Distribution Management 27(4): pp. 154-165.

Dholakia, R. R., B. Pedersen and N. Hikmet (1995). "Married Males and Shopping: Are they Sleeping Partners?" International Journal of Retail and Distribution Management 3(23): pp. 27-33.

Dickson, J. P. and D. L. MacLachlan (1990). "Social Distance and Shopping Behaviour." Journal of the Academy of Marketing Science 18(Spring): pp. 224-234.

Donegan, P. (1986). "The Myth of the Male Shopper." Progressive Grocer May: pp. 36-42. 
Fox, G. L. and V. M. Murray (2000). "Gender and Families: Feminist Perspectives and Family Research." Journal of Marriage and Family 62(1): 1160-1172.

Gardner, M. (2004). "What Men Want - In the Supermarket." The Christian Science Monitor 23(1): pp. 11-15.

Hansen, T. (2005). "Perspectives on Consumer Decision Making: An Integrated Approach." Journal of Consumer Behaviour 4(6): pp. 420-438.

Harris, R. J. and J. M. Firestone (1998). "Changes in Predictors of Gender Role Ideologies among Women: A Multivariate Analysis." Journal of Behavioural Sciences 2(1): pp. $15-23$.

Helgesen, O. and E. Nesset (2010). "Gender, Store Satisfaction and Antecedents: A case Study of a Grocery Store." Journal of Consumer Marketing 27(2): pp. 114-126.

Iacobucci, D. and A. Ostrom (1993). "Gender Differences in the Impact of Core and Relational Aspects of Services on the Evaluation of Service Encounters." Journal of Consumer Psychology 2(3): 257-287.

IBIS World Industry Report (2006). Supermarkets and Other Grocery (Except Convenience) Stores in Australia G5111. Melbourne, IBIS World Pty Ltd.

Jones, M. Y., S. Vilches-Montero, M. T. Spence, S. A. Eroglu and K. A. Machleit (2010). "Do Australian and American Consumers Differ in their Perceived Shopping Experiences? A Bi-Cultural Analysis." International Journal of Retail and Distribution Management 38(8): pp. 578-596.

Leaper, C. (2000). The Social Construction and Socialization of Gender During Development. Toward a Feminist Developmental Psychology. . P. H. Miller and E. K. Scholnick. New York, Routledge.

Leong, S. W. (1993). "Consumer Decision Making for Common, Repeat-Purchase Products: A Dual Replication." Journal of Consumer Psychology 2(2): pp. 193-208.

Lichtenstein, D. R., R. D. Netemeyer and S. Burton (1990). "Distinguishing Coupon Proneness from Value Consciousness: An Acquisition-Transaction Utility Theory." Journal of Marketing 54(July): pp. 54-67.

Lichtenstein, D. R., N. M. Ridgeway and R. D. Netemeyer (1993). "Price Perceptions and Consumer Shopping Behaviour: A Field Study." Journal of Marketing Research 30(May): pp. 234-245.

Mazumdar, T. and P. Papatla (1995). "Effects of Shopping Basket Size on Price and Promotion Responses." Pricing Strategy and Practice 3(3): pp. 16-24.

Min, H. (2010). "Evaluating the Comparative Service Quality of Supermarkets using the Analytic Hierarchy Process." The Journal of Services Marketing 24(4): 283-292.

Miranda, M. J., L. Konya and I. Havrila (2005). "Shoppers' Satisfaction Levels are not the only Key to Store Loyalty." Marketing Intelligence and Planning 23(2): pp. 220-232.

Murcott, A. (2000). "Invited Presentation: Is It Still a Pleasure to Cook for Him? Social Changes in the Household and the Family." Journal of Consumer Studies and Home Economics 24(2): pp. 78-84.

Noble, S. M., D. A. Griffith and M. T. Adjei (2006). "Drivers of Local Merchant Loyalty: Understanding the Influence of Gender and Shopping Motives." Journal of Retailing 82(3): pp. 177-188.

Otnes, C., T. M. Lowrey and L. J. Shrum (1997). "Toward an Understanding of Consumer Ambivalence." Journal of Consumer Research 24(1): pp. 80-93.

Otnes, C. and M. A. McGrath (2001). "Perceptions and realities of male shopping behavior." Journal of Retailing Volume 77(Issue 1, Spring): 111-137.

Piper, W. S. and L. M. Capella (1993). "Male Grocery Shoppers Attitudes and Demographics." International Journal of Retail and Distribution Management 21(5): pp. 22-30. 
Piron, F. (2002). "Singaporean Husbands and Grocery Shopping: An Investigation into Claims of Changing Spousal Influence." Singapore Management Review 24(1): pp. 51-66.

Poggio, B. (2006). "Outline of a Theory of Gender Practices." Gender, Work and Organization 13(3): 225-233.

Polegato, R. and J. L. Zaichkowsky (1994). "Family Food Shopping: Strategies used by Husbands and Wives." Journal of Consumer Affairs 28(2): pp. 278-300.

Potuchek, J. L. (1992). "Employed Wives' Orientations to Breadwinning: A Gender Theory Analysis." Journal of Marriage and the Family 54(3): 548-558.

Qualls, W. J. (1987). "Household Decision Behaviour: The Impact of Husbands' and Wives' Sex Role Orientation." Journal of Consumer Research 27(September): pp. 264-279.

Richbell, S. and V. Kite (2007). "Night Shoppers in the "Open 24 hours" Supermarket: A Profile." International Journal of Retail and Distribution Management 35(1): pp. 54-68.

Schurer, M. (1997). "A Shining Reputation." Supermarket Business 52(8): 98-99.

Seth, N., S. G. Deshmukh and P. Vrat (2005). "Service quality models: a review." International Journal of Quality \& Reliability Management 22(9): 913-949.

Shilling, C. (2003). The Body and Social Theory. California,, Sage.

Solgaard, H. S. and T. Hansen (2003). "A Hierarchical Bayes model of Coice Between Supermarket Formats." Journal of Retailing and Consumer Services 10(3): 169-180.

Synott, A. (1993). The Body Social: Symbolism, Self and Society. New York, Routledge.

Thomas, A. and R. Garland (2004). "Grocery Shopping: List and Non-List Usage." Marketing Intelligence and Planning 22(6): pp. 623-635.

Torres, I. M., T. A. Summers and B. D. Belleau (2001). "Men's Shopping Satisfaction and Store Preferences." Journal of Retailing and Consumer Services 8(4): pp. 205-212.

Trautrims, A., D. B. Grant, J. Fernie and T. Harrison (2009). "Optimizing On-Shelf Availability for Customer Service and Profit." Journal of Business Logistics 30(2): 231247.

Underhill, P. (1999). Why We Buy: The Science of Shopping. New York, Simon \& Schuster.

Urbany, J. E., P. E. Dickson and R. Kalapurakal (1996). "Price Search in the Retail Grocery Market." Journal of Marketing 60(4): pp. 91-104.

Williams, T. G. (2002). "Social Class Influence on Purchase Evaluation Criteria." The Journal of Consumer Marketing 19(3): pp. 249-277.

Zeithaml, V. A. (1985). "The New Demographics and Market Fragmentation." Journal of Marketing 49(3): pp. 64-75.

Zinn, W. and P. C. Liu (2001). "Consumer response to retail stockouts." Journal of Business Logistics 22( 1): 49-72.

Zinn, W. and P. C. Liu (2008). "A Comparison of Actual and Intended Consumer Behavior in Response to Retail Stockouts." Journal of Business Logistics 29(2): 141-161. 
Table 1 - Store Characteristics, Items and Author/s

\begin{tabular}{|c|c|c|}
\hline The importance:- & Items & Authors \\
\hline $\begin{array}{l}\text {...of in store promotions and weekly } \\
\text { specials }\end{array}$ & $\begin{array}{l}\text { Weekly Specials } \\
\text { Regular Discounts } \\
\text { Frequent promotions }\end{array}$ & $\begin{array}{l}\text { Polegato and } \\
\text { Zaichkowsky } 1994\end{array}$ \\
\hline $\begin{array}{l}\text {...placed on the effective staffing of } \\
\text { serviced departments }\end{array}$ & $\begin{array}{l}\text { Well staffed departments } \\
\text { Served quickly } \\
\text { No waiting }\end{array}$ & $\begin{array}{l}\text { Donegan 1986; } \\
\text { Torres, Summers et } \\
\text { al. } 2001 \text {. }\end{array}$ \\
\hline $\begin{array}{l}\text {...of the availability of advertised } \\
\text { specials and promotional lines }\end{array}$ & $\begin{array}{l}\text { In stock specials } \\
\text { No specials out of stock } \\
\text { Specials I want }\end{array}$ & $\begin{array}{l}\text { Polegato and } \\
\text { Zaichkowsky } 1994\end{array}$ \\
\hline $\begin{array}{l}\text {...of friendly, efficient and accurate } \\
\text { register operations }\end{array}$ & $\begin{array}{l}\text { Accurate operators } \\
\text { Friendly operators } \\
\text { Efficient operators }\end{array}$ & $\begin{array}{l}\text { Deitrich 1981; } \\
\text { Zeithaml 1985 }\end{array}$ \\
\hline $\begin{array}{l}\text {...consumers considered easy access, } \\
\text { egress and sufficient car parking }\end{array}$ & $\begin{array}{l}\text { Easy parking } \\
\text { Easy access to carpark } \\
\text { Parcel pickup area }\end{array}$ & Donegan 1986 \\
\hline $\begin{array}{l}\text {...placed on product availability, being } \\
\text { in stock and limited stock outs }\end{array}$ & $\begin{array}{l}\text { Well stocked shelves } \\
\text { Products I want } \\
\text { No out of stocks }\end{array}$ & Donegan 1986 \\
\hline $\begin{array}{l}\text {...of convenience associated with } \\
\text { trading times and locality }\end{array}$ & $\begin{array}{l}\text { Convenient locations } \\
\text { Supermarket easy to find } \\
\text { Quality food handling }\end{array}$ & $\begin{array}{l}\text { Zeithaml } 1985 \\
\text { Polegato and } \\
\text { Zaichkowsky } 1994\end{array}$ \\
\hline $\begin{array}{l}\text {...of cleanliness and hygienic practices } \\
\text { in relation to food handling }\end{array}$ & $\begin{array}{l}\text { Cleanliness } \\
\text { Hygienic practices } \\
\text { Quality food handling }\end{array}$ & Donegan 1986 \\
\hline ...quality fresh food & $\begin{array}{l}\text { Quality fresh food } \\
\text { Great tasting fresh food } \\
\text { Healthy fresh food }\end{array}$ & Zeithaml 1985 \\
\hline $\begin{array}{l}\text {...consistent, stable, everyday low } \\
\text { prices }\end{array}$ & $\begin{array}{l}\text { Low, everyday prices } \\
\text { Consistent prices } \\
\text { Competitive prices }\end{array}$ & $\begin{array}{l}\text { Polegato and } \\
\text { Zaichkowsky } 1994\end{array}$ \\
\hline
\end{tabular}


Table 2 - Comparison of Means - Singular Store Characteristics Items and Gender

\begin{tabular}{|l|c|c|c|}
\hline & Male & Female & $\begin{array}{l}\text { Sig. } \\
\text { Diff }\end{array}$ \\
\hline Promotions and Specials & & & \\
\hline Regular discounts & 1.99 & 1.15 & .000 \\
\hline Weekly specials & 1.84 & 1.13 & .000 \\
\hline Frequent promotions & 2.04 & 1.24 & .000 \\
\hline Staffing of serviced departments & & & \\
\hline No waiting & 1.24 & 1.57 & .000 \\
\hline Served quickly & 1.23 & 1.53 & .000 \\
\hline Well staffed departments & 1.63 & 1.66 & .745 \\
\hline Advertised specials - promotions & & & \\
\hline In stock specials & 2.07 & 1.27 & .000 \\
\hline No specials out of stock & 2.21 & 1.27 & .000 \\
\hline Specials I want & 2.01 & 1.26 & .000 \\
\hline Efficient and accurate operations & & & \\
\hline Friendly operators & 2.69 & 1.45 & .000 \\
\hline Accurate operators & 2.31 & 1.56 & .000 \\
\hline Efficient operators & 1.48 & 1.45 & .738 \\
\hline Easy access & & & \\
\hline Easy access to carparks & 3.01 & 1.46 & .000 \\
\hline Easy parking & 2.20 & 1.46 & .000 \\
\hline Parcel pickup area & 4.34 & 3.64 & .000 \\
\hline Product availability & & & \\
\hline Well stocked shelves & 2.17 & 1.52 & .000 \\
\hline Products I want & 2.96 & 1.44 & .000 \\
\hline No out of stocks & 2.36 & 1.47 & .000 \\
\hline Convenience, trading times, locality & & & \\
\hline Supermarket easy to find & 2.49 & 1.43 & .000 \\
\hline Supermarket easy to get to & 2.56 & 1.43 & .000 \\
\hline Convenient locations & 2.29 & 1.40 & .000 \\
\hline Cleanliness and hygiene & & & \\
\hline Hygienic practices & 2.56 & 1.22 & .000 \\
\hline Cleanliness & 2.60 & 1.39 & .000 \\
\hline Quality food handling & 2.81 & 1.22 & .000 \\
\hline High quality fresh food & & & \\
\hline Great tasting fresh food & & 1.22 & .000 \\
\hline Healthy fresh food & & \\
\hline Quality fresh food & & 1.42 & .000 \\
\hline Consistent, stable, low prices & & .000 \\
\hline Consistent prices & & .000 \\
\hline Competitive prices & & \\
\hline Low, everyday prices & & .000 \\
\hline
\end{tabular}


Table 3 - Factor Structure of Store Characteristics

\begin{tabular}{|c|c|c|c|}
\hline Structure & Mean & StdDev & Loadings \\
\hline Weekly promotions and specials & \multirow[b]{2}{*}{1.57} & \multirow[b]{2}{*}{.66} & \multirow[b]{2}{*}{.952} \\
\hline Regular discounts & & & \\
\hline Weekly specials & 1.49 & .56 & .923 \\
\hline Frequent promotions & 1.64 & .89 & .847 \\
\hline $\begin{array}{rr}\text { Variance Explained } 82.53 \% \\
\end{array}$ & \multicolumn{3}{|c|}{ Cronbach Alpha $\quad .89$} \\
\hline \multicolumn{3}{|l|}{ Well Staffed\& serviced departments } & \multirow[b]{2}{*}{.944} \\
\hline No waiting & 1.41 & .57 & \\
\hline Served quickly & \multirow{2}{*}{$\begin{array}{l}1.38 \\
1.65\end{array}$} & .55 & .943 \\
\hline Well staffed departments & & .62 & .737 \\
\hline $\begin{array}{cc}\text { Variance Explained } 77.50 \% \\
\end{array}$ & \multicolumn{3}{|c|}{ Cronbach Alpha $\quad .84$} \\
\hline $\begin{array}{l}\text { Being in stock of advertised specials - } \\
\text { promotions throughout the week }\end{array}$ & \multirow[b]{2}{*}{1.67} & \multirow[b]{2}{*}{.63} & \multirow[b]{2}{*}{.913} \\
\hline In stock specials & & & \\
\hline No specials out of stock & 1.74 & .68 & .949 \\
\hline Specials I want & 1.63 & .68 & .913 \\
\hline Variance Explained $85.62 \%$ & Cron & ch Alpha & \\
\hline Accurate, efficient \& friendly operators & & & \\
\hline Friendly operators & 2.07 & .91 & .907 \\
\hline Accurate operators & 1.93 & .67 & .891 \\
\hline Efficient operators & 1.46 & .71 & .514 \\
\hline $\begin{array}{rr}\text { Variance Explained } 62.72 \% \\
\end{array}$ & Cron & ch Alpha & \\
\hline Easy access and parking & & & \\
\hline Easy access to carparks & 2.42 & 1.20 & .904 \\
\hline Easy parking & 1.83 & .85 & .880 \\
\hline Parcel pickup area & 4.01 & 1.04 & .598 \\
\hline $\begin{array}{cc}\text { Variance Explained } \quad 65.00 \% \\
\end{array}$ & Cron & ch Alpha & \\
\hline Well-stocked shelves and product availability & & & \\
\hline Well stocked shelves & 1.85 & .58 & .839 \\
\hline Products I want & 1.70 & .59 & .858 \\
\hline No out of stocks & 1.92 & 1.41 & .664 \\
\hline Variance Explained $62.71 \%$ & Cron & ch Alpha & \\
\hline $\begin{array}{l}\text { Convenience, trading times, locality and } \\
\text { convenient locations }\end{array}$ & & & \\
\hline Supermarket easy to find & 1.96 & .90 & .968 \\
\hline Supermarket easy to get to & 2.01 & .93 & .950 \\
\hline Convenient locations & 1.85 & .78 & .908 \\
\hline $\begin{array}{ll}\text { Variance Explained } 88.81 \% \\
\end{array}$ & Cron & ch Alpha & \\
\hline Cleanliness and hygiene & & & \\
\hline Hygienic practices & 1.89 & .91 & .934 \\
\hline Cleanliness & 1.99 & .86 & .918 \\
\hline Quality food handling & 2.02 & 2.02 & .714 \\
\hline $\begin{array}{rr}\text { Variance Explained } & \mathbf{7 4 . 1 6} \% \\
\end{array}$ & Cron & ch Alpha & \\
\hline High quality fresh food & & & \\
\hline Great tasting fresh food & 1.94 & .76 & .985 \\
\hline Healthy fresh food & 1.93 & .77 & .968 \\
\hline Quality fresh food & 1.89 & .74 & .951 \\
\hline $\begin{array}{rr}\text { Variance Explained } 93.71 \% \\
\end{array}$ & Cron & ch Alpha & \\
\hline
\end{tabular}


Consistent, stable, low prices

Consistent prices

\begin{tabular}{l|l|l} 
& & \\
1.61 & .62 & .986
\end{tabular}

Competitive prices

1.62

.63

.961

Low, everyday prices

1.64

.61

.684

Variance Explained $\quad 95.46 \%$

Cronbach Alpha $\quad .98$ 
Table 4 - Summated Constructs

\begin{tabular}{|l|c|c|c|}
\hline Summated Constructs & Male & Female & Sig Dif \\
\hline Weekly promotions and specials & 5.86 & 3.52 & .000 \\
\hline Well-staffed serviced departments & 4.11 & 4.76 & .000 \\
\hline $\begin{array}{l}\text { Being in stock of advertised specials - promotions throughout } \\
\text { the week }\end{array}$ & 6.30 & 3.80 & .000 \\
\hline Accurate, efficient and friendly register operators & 6.49 & 4.46 & .000 \\
\hline Easy access and parking & 9.59 & 6.95 & .000 \\
\hline Well-stocked shelves and product availability & 6.49 & 4.43 & .000 \\
\hline Convenience, trading times, locality and convenient locations & 7.34 & 4.29 & .000 \\
\hline Cleanliness and hygiene & 7.98 & 3.83 & .000 \\
\hline High quality fresh food & 7.29 & 4.24 & .000 \\
\hline Consistent, stable, low prices & 6.12 & 3.61 & .000 \\
\hline
\end{tabular}


Table 5 - ANOVA - New Variables - Age, Income, Education\& Occupation

\begin{tabular}{|l|c|c|c|c|}
\hline $\begin{array}{c}\text { Dependant } \\
\text { Variable }\end{array}$ & Measures & \% & Valid \% & Cumulative \\
\hline \multirow{3}{*}{ Gender } & Male & $50 \%$ & $50 \%$ & $50 \%$ \\
\hline \multirow{3}{*}{ Age } & Female & $50 \%$ & $50 \%$ & $100 \%$ \\
\hline \multirow{3}{*}{ Income } & $<35$ years & $52.5 \%$ & $52.5 \%$ & $52.5 \%$ \\
& $>36$ years & $47.5 \%$ & $47.5 \%$ & $100 \%$ \\
\hline \multirow{3}{*}{ Education } & $<\$ 44 \mathrm{k}$ per & $33.6 \%$ & $33.6 \%$ & $33.6 \%$ \\
\hline \multirow{3}{*}{ Occupation } & annum & $66.4 \%$ & $66.4 \%$ & $100 \%$ \\
& $>\$ 45 \mathrm{k}$ per & & & \\
\hline & annum & & & $64.3 \%$ \\
& Non-Tertiary & $64.3 \%$ & $64.3 \%$ & $100 \%$ \\
\hline & Tertiary & $35.7 \%$ & $35.7 \%$ & $62.9 \%$ \\
\hline
\end{tabular}

Table 6: ANOVA: Between-Subjects Effects

\begin{tabular}{|ll|r|r|r|r|r|}
\hline Source & $\begin{array}{l}\text { Dependent } \\
\text { Variable }\end{array}$ & $\begin{array}{c}\text { Sum of } \\
\text { Squares }\end{array}$ & df & \multicolumn{1}{c|}{$\begin{array}{c}\text { Mean } \\
\text { Square }\end{array}$} & \multicolumn{1}{c|}{ F } & Sig. \\
\hline Gender & Promotions & 30.425 & 1 & 30.425 & 14.032 & 0.000 \\
& Staffing & 0.370 & 1 & 0.370 & 0.164 & 0.686 \\
& Specials & 44.017 & 1 & 44.017 & 25.111 & 0.000 \\
& Service & 32.267 & 1 & 32.267 & 14.332 & 0.000 \\
& Access & 50.636 & 1 & 50.636 & 11.051 & 0.001 \\
& In stock & 41.786 & 1 & 41.786 & 12.760 & 0.000 \\
& Convenience & 90.576 & 1 & 90.576 & 24.282 & 0.000 \\
& Clean & 189.995 & 1 & 189.995 & 68.288 & 0.000 \\
& Quality & 135.706 & 1 & 135.706 & 55.077 & 0.000 \\
& Prices & 45.163 & 1 & 45.163 & 28.693 & 0.000 \\
\hline Education & Clean & 10.996 & 1 & 10.996 & 3.952 & 0.048 \\
\hline Occupation & Prices & 7.704 & 1 & 7.704 & 4.894 & 0.028 \\
\hline Age \& Income & Prices & 13.585 & 1 & 13.585 & 8.631 & 0.004 \\
\hline Gender \& Education & Quality & 14.906 & 1 & 14.906 & 6.049 & 0.015 \\
\hline Age \& Education & In stock & 18.413 & 1 & 18.413 & 5.623 & 0.018 \\
& Quality & 12.555 & 1 & 12.555 & 5.095 & 0.025 \\
\hline Gender \& & Quality & 17.773 & 1 & 17.773 & 7.213 & 0.008 \\
Occupation & Convenience & 17.785 & 1 & 17.785 & 4.768 & 0.030 \\
\hline Age \& Occupation & Prices & 12.207 & 1 & 12.207 & 7.756 & 0.006 \\
\hline Age \& Income \& & & & & & & \\
Occupation & & 8.724 & 1 & 8.724 & 4.977 & 0.027 \\
\hline Gender \& Education & Specials & & & & & \\
\hline \& Occupation & & & & & & \\
\hline
\end{tabular}


Table 7: Univariate ANOVA: Mean Differences between Groups

\begin{tabular}{|c|c|c|c|c|c|}
\hline \multicolumn{2}{|l|}{$\begin{array}{l}\text { Education } \\
\text { Cleanliness }\end{array}$} & \multirow[t]{2}{*}{ Mean } & \multirow[t]{2}{*}{ Std. Error } & \multicolumn{2}{|c|}{ 95\% Confidence Interval } \\
\hline & & & & $\begin{array}{l}\text { Lower } \\
\text { Bound }\end{array}$ & $\begin{array}{l}\text { Upper } \\
\text { Bound }\end{array}$ \\
\hline \multicolumn{2}{|c|}{ Non-tertiary Educated } & 1.804 & .063 & 1.680 & 1.928 \\
\hline \multicolumn{2}{|c|}{ Tertiary Educated } & 2.167 & .085 & 2.000 & 2.333 \\
\hline \multicolumn{2}{|c|}{$\begin{array}{l}\text { Occupation } \\
\text { Consistent Low Prices }\end{array}$} & Mean & Std. Error & \multicolumn{2}{|c|}{ 95\% Confidence Interval } \\
\hline & & & $\begin{array}{l}\text { Lower } \\
\text { Bound }\end{array}$ & $\begin{array}{l}\text { Upper } \\
\text { Bound }\end{array}$ \\
\hline \multicolumn{2}{|c|}{ Blue Collar/Trade } & 1.456 & .043 & 1.372 & 1.540 \\
\hline \multicolumn{2}{|c|}{ White Collar/Professional } & 1.904 & .056 & 1.795 & 2.013 \\
\hline \multicolumn{2}{|c|}{$\begin{array}{l}\text { Age \& Income } \\
\text { Consistent Low Prices }\end{array}$} & Mean & Std. Error & \multicolumn{2}{|c|}{ 95\% Confidence Interval } \\
\hline \multicolumn{2}{|c|}{$\begin{array}{ll}\text { Income } & \text { Age }\end{array}$} & & & $\begin{array}{l}\text { Lower } \\
\text { Bound }\end{array}$ & $\begin{array}{l}\text { Upper } \\
\text { Bound }\end{array}$ \\
\hline \multirow[t]{2}{*}{$<A U D \$ 44,000$} & $<35$ Years & 1.326 & .077 & 1.175 & 1.478 \\
\hline & $>35$ Years & 1.116 & .079 & 0.961 & 1.271 \\
\hline \multirow[t]{2}{*}{$>A \cup D \$ 44,000$} & $<35$ Years & 1.798 & .054 & 1.692 & 1.903 \\
\hline & $>35$ Years & 1.854 & .057 & 1.742 & 1.967 \\
\hline \multicolumn{2}{|c|}{$\begin{array}{l}\text { Gender \& Education } \\
\text { Fresh Food Quality }\end{array}$} & Mean & Std. Error & \multicolumn{2}{|c|}{ 95\% Confidence Interval } \\
\hline \multicolumn{2}{|r|}{ Education } & & & $\begin{array}{l}\text { Lower } \\
\text { Bound }\end{array}$ & $\begin{array}{l}\text { Upper } \\
\text { Bound }\end{array}$ \\
\hline \multirow[t]{2}{*}{ Male } & Non-tertiary & 2.451 & .066 & 2.321 & 2.581 \\
\hline & Tertiary & 2.404 & .062 & 2.283 & 2.526 \\
\hline \multirow[t]{2}{*}{ Female } & Non-tertiary & 1.403 & .050 & 1.305 & 1.501 \\
\hline & Tertiary & 1.453 & .107 & 1.243 & 1.663 \\
\hline \multicolumn{2}{|c|}{$\begin{array}{l}\text { Education \& Age } \\
\text { Being In Stock }\end{array}$} & Mean & Std. Error & \multicolumn{2}{|c|}{ 95\% Confidence Interva } \\
\hline \multicolumn{2}{|c|}{ Education } & & & $\begin{array}{l}\text { Lower } \\
\text { Bound }\end{array}$ & $\begin{array}{l}\text { Upper } \\
\text { Bound }\end{array}$ \\
\hline \multirow[t]{2}{*}{ Non-tertiary } & $<35$ Years & 1.667 & .061 & 1.547 & 1.787 \\
\hline & $>35$ Years & 1.779 & .052 & 1.676 & 1.881 \\
\hline \multirow[t]{2}{*}{ Tertiary } & $<35$ Years & 1.930 & .063 & 1.805 & 2.054 \\
\hline & $>35$ Years & 1.897 & .099 & 1.702 & 2.091 \\
\hline \multicolumn{2}{|c|}{$\begin{array}{l}\text { Education \& Age } \\
\text { Fresh Food Quality }\end{array}$} & Mean & Std. Error & \multicolumn{2}{|c|}{ 95\% Confidence Interval } \\
\hline \multicolumn{2}{|c|}{ Education } & & & $\begin{array}{l}\text { Lower } \\
\text { Bound }\end{array}$ & $\begin{array}{l}\text { Upper } \\
\text { Bound } \\
\end{array}$ \\
\hline \multirow[t]{2}{*}{ Non-tertiary } & $<35$ Years & 1.632 & .081 & 1.472 & 1.791 \\
\hline & $>35$ Years & 1.891 & .069 & 1.754 & 2.028 \\
\hline Tertiary & $<35$ Years & 2.174 & .084 & 2.008 & 2.339 \\
\hline & $>35$ Years & 2.149 & .131 & 1.891 & 2.408 \\
\hline
\end{tabular}




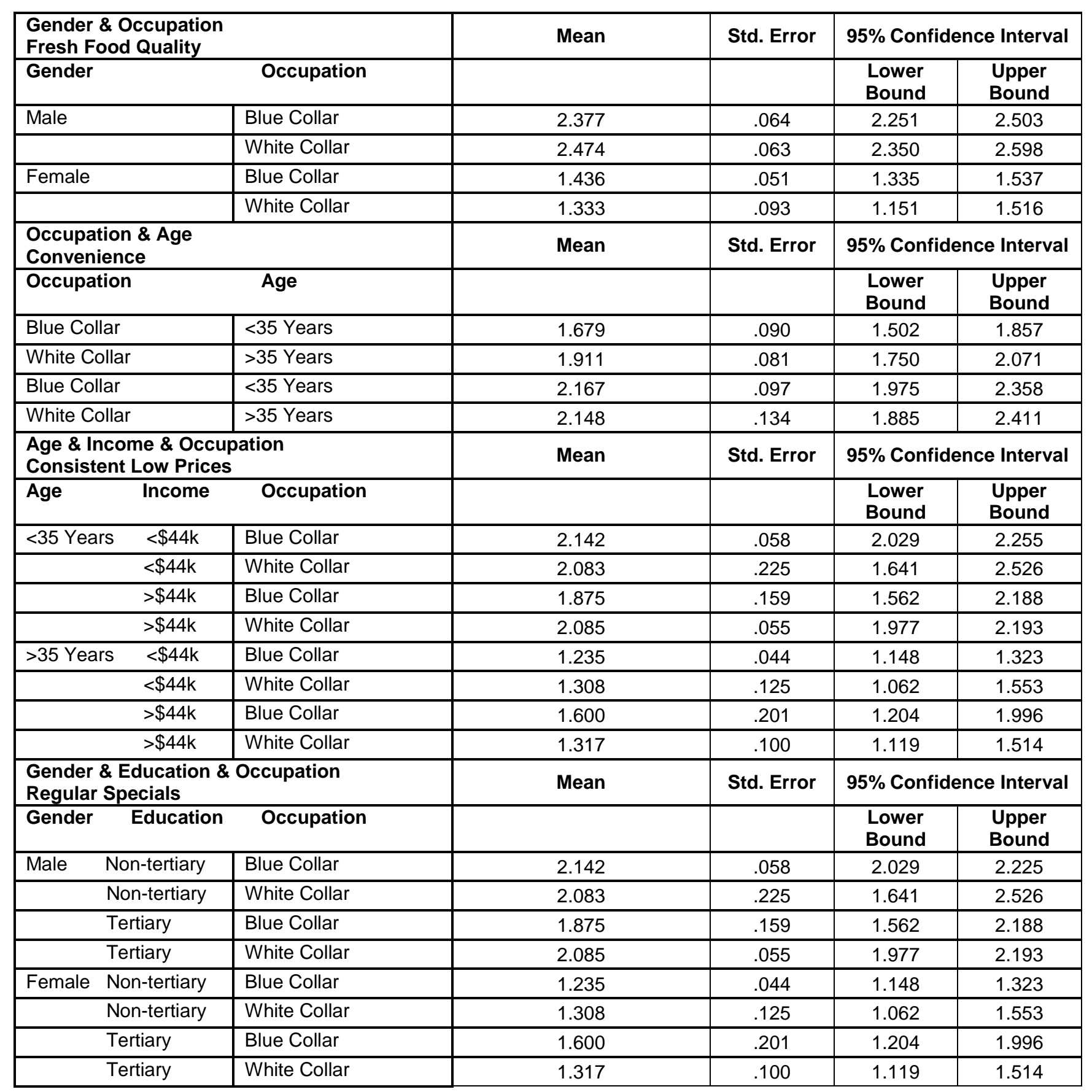

